\title{
White Turmeric Rhizome Protection Effect of against Lung Tissue Damage in Copper Sulfate-Induced Wistar Rats
}

\author{
Linda Chiuman, Fahrul Azmi Tanjung, Djamin \\ Faculty of Medicine, Universitas Prima Indonesia, Medan, Indonesia
}

\begin{abstract}
One of common heavy metals that pollute rivers in Indonesia is copper, which can damage various organs, including the lungs. As a potential natural herbal medicine, white turmeric rhizome has antioxidant properties that potentially protect the body from copper pollution. This study aimed to explore the potential of the white turmeric rhizome (Curcuma zedoaria) to provide a protective effect on the lungs against copper contamination. This study was an experimental study performed in June 2020 on 25 copper-induced Wistar rats which were divided into five groups: negative group that received $1 \mathrm{~mL}$ of copper sulfate suspension at the $12^{\text {th }}$ to $14^{\text {th }}$ day; positive group that received $10 \mathrm{mg} / 200 \mathrm{gBW}$ of ethanol extract from white turmeric without copper sulfate suspension; and three experimental groups that received $10 \mathrm{mg} / 200 \mathrm{gBW}, 20 \mathrm{mg} / 200 \mathrm{gBW}$, and $40 \mathrm{mg} / 200$ gBW of ethanol extract from white turmeric every day, respectively, followed by copper sulfate suspension at the $12^{\text {th }}-14^{\text {th }}$ day. After 14 days, the rats were sacrificed by chloroform inhalation and the lung was excised and processed for histopathology preparation. The edema, hemorrhage, leukocyte infiltration, and alveolar septal thickness were evaluated from the lung tissue perparation. The score of tissue damage was express as median (range) and analyzed using the Kruskal-Wallis test. The result of this study shows that there was a significant difference in lung tissue score among all groups of treatment ( $p$-value=0.001). The experimental group with highest dosage extract presented a good protection effect as well as the positive group. Hence, white turmeric has a good protective property for the lung against damages caused by copper contamination.
\end{abstract}

Keywords: Copper sulfate, ethanol, lung, white turmeric

\section{Efek Proteksi dari Rimpang Kunyit Putih terhadap Kerusakan Jaringan Paru pada Tikus Wistar yang Diinduksi Tembaga Sulfat}

\begin{abstract}
Abstrak
Salah satu logam berat yang umum mencemari beberapa sungai di Indonesia adalah tembaga yang dapat merusak beragai organ seperti paru-paru. Rimpang kunyit putih sebagai sumber daya alam potensial memiliki sifat antioksidan yang berpotensi melindungi tubuh dari pencemaran tembaga. Oleh karena itu, penelitian ini bertujuan mengeksplorasi potensi rimpang kunyit putih (Curcuma zedoaria) dalam memberikan efek perlindungan pada paru-paru terhadap logam tembaga. Penelitian ini merupakan penelitian eksprimental menggunakan 25 ekor tikus pada Juni 2020. Tikus-tikus ini dibagi menjadi 5 kelompok, yaitu kelompok negatif diberi $1 \mathrm{~mL}$ suspensi tembaga sulfat pada hari ke 12-14, kelompok positif mendapat ekstrak etanol kunyit putih $10 \mathrm{mg} / 200 \mathrm{gBB}$ tanpa suspensi tembaga sulfat, kelompok percobaan menerima ekstrak etanol $10 \mathrm{mg} / 200 \mathrm{gBB}, 20 \mathrm{mg} / 200 \mathrm{gBB}$, dan $40 \mathrm{mg} / 200 \mathrm{gBB}$ dari kunyit putih setiap hari diikuti dengan suspensi tembaga sulfat pada hari ke 12-14. Setelah 14 hari, tikus dikorbankan dengan cara menghirup kloroform dan paru-paru di eksisi dan diproses untuk dibuat preparat histopatologi. Edema, perdarahan, infiltrasi leukosit, dan ketebalan septum alveolar dievaluasi dari jaringan paru. Skor kerusakan jaringan dinyatakan sebagai median (range) dan dianalisis dengan uji kruskallwallis. Hasil penelitian menunjukkan bahwa terdapat perbedaan yang signifikan skor jaringan paru pada semua kelompok perlakuan (nilai $\mathrm{p}=0,001$ ). Ekstrak dosis tertinggi menunjukkan efek perlindungan yang baik sebaik kelompok positif. Oleh karena itu, kunyit putih memiliki efek perlindungan yang baik pada paru-paru terhadap tembaga.
\end{abstract}

Kata kunci: Etanol, kunyit putih, tembaga sulfat, paru-paru

Corresponding Author: Linda Chiuman, Faculty of Medicine Universitas Prima Indonesia, Jalan Belanga No. 1 Simp. Ayahanda Medan, North Sumatra, Indonesia, Email: lindachiuman@unprimdn.ac.id 


\section{Introduction}

The lung is a vital organ which has an essential function in the distribution of oxygen througout the body. Various factors can damage the lung, such as gene mutations, irritants, and hazardous chemicals. Hazardous chemicals can come from environmental pollution. Several studies have been conducted to investigate the level of environmental pollution that included tin, mercury, arsenic, aluminum, copper, nickel, lead, antimony, bromine, bismuth, and vanadium. ${ }^{1}$

Heavy metal pollution is an important issue for Indonesia and various countries in the world that there are many studies conducted globally to understand this issue. One of these studies reported that Some Rainwater Tanks in Adelaide Region, Australia, have been polluted by various heavy metals, with the highest being lead. Of the 53 samples collected from the tanks, lead is detected in 47 tanks with a level of above the ADWG (Australian Drinking Water Guidelines) threshold. Other heavy metals like zinc, cadmium, and copper are detected in fewer samples, especially in the Adelaide Hills and foothills ${ }^{2}$.

On the other hand, a study from India also reported a similar result by declaring six types of heavy metal, i.e., $\mathrm{Mn}, \mathrm{Cr}, \mathrm{Cu}, \mathrm{Zn}, \mathrm{Pb}$, and $\mathrm{Fe}$, have polluted the Ganging river at various sites in the Allahabad region. Other rivers in India also show a similar level of pollution ${ }^{3}$. In Indonesia, several studies have also been conducted to investigate water pollution. Septiono and Roosmini ${ }^{4}$ reported that the heavy metal pollution with the highest level in Citarum River, Indonesia, is chromium based on the analysis on fish, water, and river sediments that were collected from several sampling points. Other heavy metals that are also identified as pollutants in the river are copper and cadmium. Another study conducted in Bone River showed that the levels of As, Hg, and $\mathrm{Pb}$ are high in this river, with a level that is around 1,000 to 10,000 times higher than the safe range for drinking water as defined by the WHO. This pollution is suspected to come from the artisanal small-scale gold mine (ASGM) activities.

Based on data from various studies, including those mentioned above, one of the heavy metals that frequently cause water pollution in Indonesia is copper. Prolonged exposure to copper can irritate the nose, mouth, eyes, headaches, and trigger digestive disorders. Excessive copper intake can also cause nervous and lung damages, as well as circulatory disorders. ${ }^{5}$ Thus, copper is a compound that can damage various body organs, which makes protection against this heavy metal pollution necessary.

The earth provides some natural resources to protect human body from heavy metals pollution, including copper. One of such natural resources is white turmeric rhizome (Curcuma Zedoaria) that contains various phytochemicals like Furanodiene, furanodienone, zederone, curzerenone, curzeone, germacrone, 13-hydroxygermacrone, dehydrocurdione, curcumenone, zedoaronediol, 13-hydroxycurzerenone, 1oxocurzerenone, curcolone, procurcumenol, ermanin, curcumin, and a mixture of stigmast-4-en-3,6 dione and stigmasta-4,22-dien-3,6. In addition, as one of the vital phytochemicals, curcumin contains some pharmacological properties, including antioxidative stress, anti-inflammation, and antiapoptosis. Also, it plays a role in multiple molecular targets of many pathways; thus protecting many organ functions. Huang et al. reported that curcumin has an excellent alleviating effect on lung injury caused by various causes through complicated mechanisms of action..$^{6-8}$ Due to these reasons, this study was designed to explore the potential of the white turmeric rhizome (Curcuma zedoaria) to provide a protective effect on the lungs against copper using rats as the experimental animal.

\section{Methods}

This study was an experimental study using rats as the experimental animal which was performed in June 2020 at the Pharmacology Laboratory of the Faculty of Medicine, Universitas Prima Indonesia. This study has been approved by the Health Research Ethics Committee of Universitas Prima Indonesia under the ethical clearance No. 016/KEPK/UNPRI/V/2020.

Materials used in this study were $96 \%$ ethanol, white turmeric rhizome, sodium carboxy-methylcellulose (Na-CMC), Copper sulfate pentahydrate (Merck, Catalogue No. 1027901000), aquadest, rat pellets, chloroform, alcohol, formalin, xylol, paraffin, and Hematoxylin-eosin (HE) staining powder.

White turmeric, also known as Curcuma zedoaria, was obtained from UPT Materia Medica Batu, East Java. The white turmeric was cleaned, dried, and mashed to get the simplicia powder. The powder was then soaked into $96 \%$ ethanol for 24 hours, filtered, and the filtrate was collected. The process was repeated two times 
and the final mixture was evaporated by a rotary evaporator at $50^{\circ} \mathrm{C}$ until the filtrate became concentrated ${ }^{9,10}$.

After that, the ethanol extract was suspended into the sodium carboxy-methylcellulose to form an oral suspension. The amount of 0.5 grams sodium carboxy-methylcellulose was spread on the surface of $30 \mathrm{~mL}$ hot water in the mortar for 15 minutes until it formed a clear suspension. The suspension was grounded until it was homogenous and was dissolved until 100 $\mathrm{mL}$. The obtained oral suspension was used as a vehiculum for extract and copper sulfate pentahydrate. The amount of $45 \mathrm{mg}, 67.5 \mathrm{mg}$, and $90 \mathrm{mg}$ of extracts was mixed into $5 \mathrm{~mL}$ of $0.5 \%$ sodium carboxy-methylcellulose suspension to form the extract suspension dosages of 10 $\mathrm{mg} / 200 \mathrm{gBW}, 20 \mathrm{mg} / 200 \mathrm{gBW}$, and $40 \mathrm{mg} / 200$ gBW, respectively. Finally, the amount of $0.36 \mathrm{mg}$ Copper sulfate pentahydrate was mixed into 5 $\mathrm{mL}$ of $0.5 \%$ sodium carboxy-methylcellulose to form copper sulfate suspension. ${ }^{11}$

This study used 25 rats that were divided into five groups. The following table describes the intervention given to each group.

After 14 days of intervention, all rats were sacrificed by inhalation of chloroform in a closed room. After that, the rats' abdomen was incised horizontally. The lungs of the rats were collected from the chest cavity and washed with normal saline. The washed lungs were soaked into $10 \%$ formalin and was reserved until tissue processing. ${ }^{10,11}$

The lungs were sliced to a thickness of 4-6 $\mathrm{mm}$ and was dehydrated with different concentrations of alcohol (70\%, 80\%, 90\%, and $95 \%$ ) for 24 hours and then dehydrated with $100 \%$ alcohol for an hour in three repeats. Subsequently, it was purified by xylol for an hour in three repeats. The tissue was then infiltrated into the paraffin and incised to 4-5 microns thickness. Finally, the incision was attached to the slide and stained by hematoxylin-eosin (HE) staining. ${ }^{10,11}$

The lung tissue was viewed under the microscope at 100x and 400x magnifications. Four parameters were used to evaluate the lungs' histology, including edema, hemorrhage, leukocyte infiltration, and alveolar septal thickening. A scoring system was then applied on the four lung damage indices; edema (score: 0-4), hemorrhage (score: 0-4), leukocyte infiltration (score: 0-4), and alveolar septal thickening (score: $0-4$ ), which was then combined to bring a total score of $0-16$. The scoring system used to evaluate the lung histology is presented in the following table. ${ }^{12}$

This scoring system is based on the severity of lung damage and is adopted from Akcilar et al. ${ }^{12}$ scoring system for histopathology.

All scores obtained from each parameter were summed into a total score, which was then

Table 1 Intervention by Group

\begin{tabular}{|c|c|}
\hline Groups & Intervention \\
\hline Negative & $\begin{array}{l}\text { Rats received } 1 \mathrm{ml} \text { of copper sulfate pentahydrate by intragastric } \\
\text { oral tube once a day on the } 12^{\text {th }}, 13^{\text {th }} \text {, and } 14^{\text {th }} \text { days. } \\
\text { Food and Drink were given ad libitum. }\end{array}$ \\
\hline Positive & $\begin{array}{l}\text { Rats received } 1 \mathrm{ml} \text { of extract suspension dosage } 10 \mathrm{mg} / 200 \mathrm{~g} \mathrm{BW} \\
\text { by intragastric oral tube once a day every day. } \\
\text { Food and Drink were given ad libitum. }\end{array}$ \\
\hline Ethanol extract of white turmeric-I & $\begin{array}{l}\text { Rats received } 1 \mathrm{ml} \text { of extract suspension dosage } 10 \mathrm{mg} / 200 \mathrm{~g} \mathrm{BW} \\
\text { by intragastric oral tube once a day for } 14 \text { days, followed by } 1 \mathrm{~mL} \\
\text { copper sulfate pentahydrate on the } 12^{\text {th }}, 13^{\text {th }} \text {, and } 14^{\text {th }} \text { day. } \\
\text { Food and Drink were given ad libitum. }\end{array}$ \\
\hline Ethanol extract of white turmeric-II & $\begin{array}{l}\text { Rats received } 1 \mathrm{~mL} \text { of extract suspension dosage of } 20 \mathrm{mg} / 200 \mathrm{~g} \\
\text { BW by intragastric oral tube once a day for } 14 \text { days, followed by } 1 \\
\mathrm{ml} \text { of copper sulfate pentahydrate on the } 12^{\text {th }}, 13^{\text {th }} \text {, and } 14^{\text {th }} \text { day. } \\
\text { Food and Drink were given ad libitum. }\end{array}$ \\
\hline Ethanol extract of white turmeric-III & $\begin{array}{l}\text { Rats received } 1 \mathrm{ml} \text { of extract suspension dosage of } 40 \mathrm{mg} / 200 \mathrm{~g} \mathrm{BW} \\
\text { by intragastric oral tube once a day for } 14 \text { days, followed by } 1 \mathrm{ml} \text { of } \\
\text { copper sulfate pentahydrate on the } 12^{\text {th }}, 13^{\text {th }} \text {, and } 14^{\text {th }} \text { day. } \\
\text { Food and Drink were given ad libitum. }\end{array}$ \\
\hline
\end{tabular}


Table 2 Lung Tissue Scoring System

\begin{tabular}{ccccc}
\hline Score & Edema & Hemorrhage & $\begin{array}{c}\text { Leucocyte } \\
\text { Infiltration }\end{array}$ & $\begin{array}{c}\text { Alveolar Septal } \\
\text { Thickening }\end{array}$ \\
\hline 0 & None & None & $\leq 10$ cells & None \\
1 & 1 quadrant & 1 quadran & $10-24$ cells & 1 quadrant \\
3 & 3 quadrant & 3 quadran & $50-74$ cells & 3 quadrant \\
4 & 4 quadrant & 4 quadran & $\geq 75$ cells & 4 quadrant \\
\hline
\end{tabular}

used for data analysis. The total score from the histology evaluation was expressed as Median (Range), analyzed by Kruskal-Wallis, and followed by Mann-Whitney. The confidence level of this analysis was $95 \%(\alpha=0.05)$.

\section{Results}

The following table and figure showed the result of the evaluation of lung tissues from all groups. Based on the table above, the normal, positive, and highest ethanol extract groups showed no significant differences. However, these groups showed notable differences against negative groups and the other two groups from the ethanol extract of white turmeric (I and II). This means that the positive group and the highest dosage ethanol extract from white turmeric group showed a good protection effect. On the other hand, the two lower dosages did not show good protection and demonstrating lung tissue damages that are similar to the negative groups. The following figures depicted the histology view of the tissue.

\section{Discussion}

This study has answered the research question through the histology of the lung from each group of intervention. The white turmeric extract at the dose of $20 \mathrm{mg} / 200 \mathrm{gBW}-40 \mathrm{mg} / 200 \mathrm{gBW}$ does not improve lung tissue damages induced by copper. A higher dosage of white turmeric dose is required to improve the lung tissue damages induced by copper. Three groups are included as control for comparison purpose: normal, positive, and negative groups. Two groups with lower dosages of white turmeric extract present similar histology features with the negative groups such as the presence of infiltration and thickening of the alveolar septal, which can be seen at the high magnified histological view.

At $40 \mathrm{mg} / 200 \mathrm{gBW}$ of white turmeric extract and negative group, the lung tissue demonstrates some hemorrhage at the moderately magnified histological view. On the other hand, the highest dose of white turmeric extract shows similar histology features with a normal and positive group, such as decreased septal thickening of alveolar septal and infiltration, which can be seen in the medium magnification of histological view and more apparently at higher magnification. This features are not only apparent from the microscopic view, but also from the results of the scoring system used to evaluate these histology features. The scoring system analysis is outlined in Table 3.

Copper is an essential micronutrient and cofactor for a wide range of enzymes. This micronutrient balance is tightly regulated

Table 3 Lung Tissue Score by Group

\begin{tabular}{lcc}
\hline \multicolumn{1}{c}{ Groups } & Total Score & P-Value \\
\hline Normal & $4.00(0.00)$ & \\
Positive & $5.00(1.00)$ & 0.001 \\
Negative & $12.50(1.00)^{\mathrm{ab}}$ & \\
Ethanol extract of white turmeric-I & $11.50(2.00)^{\mathrm{ab}}$ & \\
Ethanol extract of white turmeric-II & $11.50(2.00)^{\mathrm{ab}}$ & \\
Ethanol extract of white turmeric-III & $4.50(1.00)^{\mathrm{c}}$ & \\
\hline
\end{tabular}

a Significant Difference at P-Value $<0.05$ against Normal Group; ${ }^{\text {b Significant Difference at P-Value }<0.05 \text { against Positive }}$ Group; ' Significant Difference at P-Value $<0.05$ against Negative Group 
Table 4 Histology View of Lug Tissue

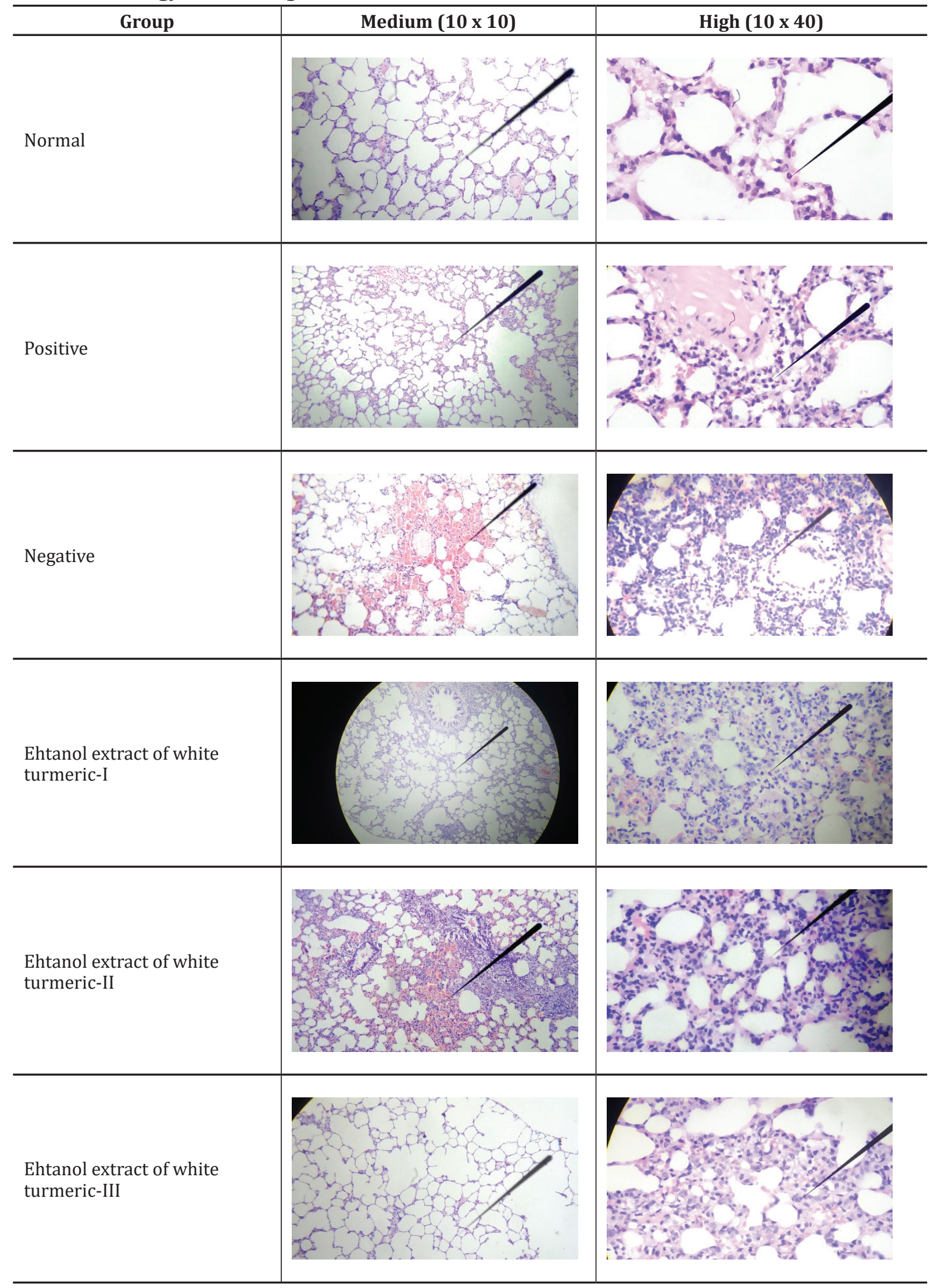


because a higher copper serum level can trigger oxidative stress that activates inflammatory responses that can affect various organs, especially lung tissue. ${ }^{13}$ The toxicity of copper for lung tissue is dose-dependent and is due to the formation of reactive oxygen species (ROS) ${ }^{14}$.

Curcuma zedoaria or white turmeric has antioxidant effects. White turmeric contains around 20 types of phytochemicals that carry antioxidant and anti-inflammatory effects. With the presence of phytochemicals, white turmeric can reduce the toxicity of copper against various organs, not only for lung tissue. Curcumin is the major phytochemical responsible for lung protection against copper that may act as an antioxidant by scavenging free radicals and endogenous oxidizing active substances. Also, curcumin acts as a regulator of antioxidant enzymes (SOD, GSH-PX, and CAT) and increases intracellular glutathione levels by maintaining histone activities of acetyltransferase in monocytes, hence, reducing damages during oxidative stress. Recently, curcumin has also been shown to have a core mechanism in protective effect viz. to promote the activation of Nrf2 signaling pathway in cell and induce the expression of phase II detoxification enzymes and antioxidants enzymes (nicotinamide quinone oxidoreductase 1 (NQO1), $\gamma$-glutamylcysteine synthetase $(\gamma$-GCS), HO- 1 , and superoxide dismutase (SOD)). These enzymes protect the body from active substances and some toxic exogens. ${ }^{8,15-17}$ This mechanism is supported by this histopathological study that demonstrates the highest dosage of white turmeric groups has a lower histopathology score, meaning a better protection effect than normal.

Some studies have investigated the protective effect of white turmeric against copper-induced damages in various organs, and the results of these studies are in line with the result of this study. Chiuman ${ }^{9}$ suggested that the white turmeric extract could improve copper-induced damages on kidney tissue, marked by lowering the serum urea and creatinine in rats. Moreover, Wardhani et al. ${ }^{18}$ also reported improved the kidney tissue demonstrated by improving glomerular function (Cystatin-C and Protein Serum). A previous study conducted by the authors also supported the results of the recent study by showing that white turmeric also improves the WBC level among copper-induced rats, especially at the highest dosage. ${ }^{9}$

Overall, the highest dose of ethanol extract from white turmeric has a protective effect on lung tissue from damages induced by copper and the positive group due to the antioxidant properties of the white turmeric.

\section{References}

1. Wilson L. Toxic metals and human health. Eck Institute Nutrition and Bioenergetics. Mexico: Eck Institute Nutrition and Bioenergetics; 2012. p. 1-37.

2. Chubaka CE, Whiley H, Edwards JW, Ross KE. Lead, zinc, copper, and cadmium content of water from South Australian rainwater tanks. Int J Environ Res Public Health. 2018;15(7):1-12.

3. Nizami G, Rehman S. Assessment of heavy metals and their effects on quality of water of rivers of Uttar Pradesh, India: A review. J Env Chem Toxicol. 2018;2(2):65-71.

4. Septiono MA, Roosmini D. Heavy metal distribution in water, sediment, and fish at upper citarum river and its potential exposure pathway to human. In: Environmental Technology \& Management Conference. Bandung; 2015. p. 1-10.

5. Sembe DT. Toksikologi lingkungan. Yogyakarta: Andi; 2015.

6. Rivera-Espinoza Y, Muriel P. Pharmacological actions of curcumin. John Wiley Sons Ltd. 2009;29(10):1457-66.

7. Lakshmi S, Padmaja G, Remani P. Antitumour Effects of Isocurcumenol Isolated from Curcuma zedoaria Rhizomes on Human and Murine Cancer Cells. Int J Med Chem. 2011;2011(253962):1-13.

8. Huang K, Shi CM, Min JQ Li L, Zhu T, Yu H, et al. study on the Mechanism of Curcumin Regulating Lung Injury Induced by Outdoor Fine Particulate Matter (PM2.5). Mediators Inflamm. 2019;2019:8613523.

9. Chiuman L. Protective Effect of Curcuma zedoaria Against Copper in Rats' White Blood Cell. Am Sci Res J Eng Technol Sci. 2019;59(1):142-8.

10. Ongko NX, Chiuman L, Ginting CN. Effect of White Turmeric Rhizome Extract (Curcuma zedoaria) on Testis Histology of Male Wistar Rat. Am Sci Res J Eng Technol Sci. 2019;55(1):69-74.

11. Mutia MS, Chiuman L. Hepatoprotective effect of citrus sinensis (L.) osbeck ethanol extract in paracetamol-induced rats efek hepatoprotektif ekstrak etanol citrus sinensis L. Osbeck pada Tikus yang Diinduksi Parasetamol. MKB. 2019;51(4):189-93.

12. Akcilar R, Akcilar A, Simsek H, Koçak 
FE, Koçak C, Yümün G, et al. Hyperbaric oxygen treatment ameliorates lung injury in paraquat intoxicated rats. Int J Clin Exp Pathol. 2015;8(10):13034-42.

13. Pereira TCB, Campos MM, Bogo MR. Copper toxicology, oxidative stress and inflammation using zebrafish as experimental model. J Appl Toxicol. 2016;36(7):876-85.

14. Lai X, Zhao H, Zhang Y, Guo K, Xu Y, Chen S, et al. Intranasal delivery of copper oxide nanoparticles induces pulmonary toxicity and fibrosis in C57BL/6 mice. Sci Rep. 2018;8(4499):1-12.

15. Sabale P,ModiA, Sabale V.CurcumalongaLinn. a phytochemical and phytopharmacological review. Res J Pharmacogn Phytochem. 2013;5(2):59-68.

16. Rajkumari S, Sanatombi K. Nutritional value, phytochemical composition, and biological activities of edible Curcuma species: A review. Int J Food Prop. 2017;20(53):266887.

17. Dosoky NS, Setzer WN. Chemical composition and biological activities of essential oils of curcuma species. Nutrients. 2018;10(1196):1-42.

18. Wardhani FM, Chiuman L, Novalinda Ginting C, Ginting SF. Role of cystatin-C as serum biomarkers in predicting glomerular function associated with copper-induced acute kidney injury. MKB. 2020;52(1):16-21.

19. Wardhani FM, Chiuman L, Novalinda Ginting C, Ginting SF, Nasution AN. Efek ekstrak kunyit putih (curcumazedoaria) sebagai nefroprotektor pada tikus putih jantan galur wistar yang diinduksi tembaga. J Indon Med Assoc. 2019;69(8):258-66. 